Audiology

Neurotology
Audiol Neurotol 2018;23:1-7

DOI: 10.1159/000486274
Received: June 8, 2017

Accepted after revision: December 13, 2017

Published online: June 22, 2018

\title{
Effect of Antioxidant Vitamins as Adjuvant Therapy for Sudden Sensorineural Hearing Loss: Systematic Review Study
}

\author{
Iman Ibrahim ${ }^{a} \quad$ Anthony Zeitouni ${ }^{b}$ Sabrina Daniela da Silvac \\ ${ }^{a}$ Department of Otolaryngology, Head and Neck Surgery, McGill University, bepartment of Otolaryngology, Head \\ and Neck Surgery, Royal Victoria Hospital, McGill University, and ${ }^{\mathrm{C} D e p a r t m e n t ~ o f ~ O t o l a r y n g o l o g y, ~ H e a d ~ a n d ~ N e c k ~}$ \\ Surgery, Jewish General Hospital, McGill University, Montréal, QC, Canada
}

\section{Keywords}

Antioxidant - Vitamin A · Vitamin C · Vitamin E · Sudden sensorineural hearing loss · Adjuvant therapy · Idiopathic sensorineural hearing loss · Oxidative stress · Reactive oxygen species $\cdot$ Reactive nitrogen species

\footnotetext{
Abstract

Importance: Sudden sensorineural hearing loss (SSNHL) is an otological emergency of unknown etiology. Recent reports showed that antioxidant drugs can benefit patients with SSNHL. This study attempted to evaluate the effect of adding antioxidant vitamins as an adjuvant therapy alongside with corticosteroids. Objective: To evaluate the effects of the 3 major antioxidant vitamins ( $A, C$, and $E$ ) as an adjuvant therapy, administered with corticosteroids, for the treatment of SSNHL in adult patients ( $\geq 18$ years). Data Sources: MEDLINE, EMBASE, PubMed, Web of Science and Cochrane electronic databases from January 1, 1995, through September 25, 2017. Study Selection: Published studies of adult patients who received antioxidant vitamins ( $A, C, E$, or any combination of these vitamins) as an adjuvant therapy in addition to the regular treatment (corticosteroids) for
}

SSNHL. Quality assessment was performed using the Cochrane Collaboration Tool for Assessing Risk of Bias. Data Extraction: Each study had a control group (conventional treatment + placebo) and a trial group (antioxidant vita$\min (\mathrm{s})+$ conventional treatment). Results: From 446 manuscripts identified in the literature, 3 studies were included in the review with 279 patients. The most common vitamins used to treat SSNHL were the 3 major antioxidant vitamins A, C, and E, combined sometimes with other antioxidants such as selenium. Conclusions and Relevance: The success of the treatment is increased in patients who received antioxidant vitamins in combination with conventional therapy.

(c) 2018 S. Karger AG, Basel

\section{Introduction}

Sudden sensorineural hearing loss (SSNHL) is a relatively common complaint in otological and audiological practices (1.5-1.7 per 100 new patients presenting in our practice). The estimated annual incidence of SSNHL is 5-30 cases per 100,000 populations, with 15,000 new cases reported annually worldwide and about 4,000 new cas-

\section{KARGER}

(c) 2018 S. Karger AG, Basel

E-Mail karger@karger.com

www.karger.com/aud
Dr. Iman Ibrahim

Department of Otolaryngology, Head and Neck Surgery, McGill University

307-201 Metcalfe Avenue, Westmount

Montreal, QC H3Z 2H7 (Canada)

E-Mail iman.ibrahim@mail.mcgill.ca 
es reported annually in the USA [Alexander and Harris, 2013]. The incidence of SSNHL increases with age, especially between 50 and 60 years old for men and women equally.

The majority of patients with SSNHL has no identifiable cause for hearing loss and is classified as "idiopathic." The diagnostic criteria for SSNHL are (a) a hearing loss of $30 \mathrm{~dB}$ (or more) over 3 contiguous pure-tone frequencies, occurring within (b) a 3-day period. This is a frustrating entity appearing usually unilaterally but in some cases bilaterally where patients are overwhelmed by the sudden loss of hearing [Hatano et al., 2008; Joachims et al., 2003; Kaya et al., 2015]. Despite the extensive research, controversy remains in the etiology and appropriate care of these patients. Some of the known risk factors include viral and bacterial infections, trauma, neoplasia, vascular disease/alteration, and side effects of drug administration, such as those of aminoglycosides and cisplatin [Lanvers-Kaminsky et al., 2017]. Evidence suggests that there is an association between SSNHL and long-term risk of stroke [WHO, 2017].

Numerous agents have been investigated for the treatment of SSNHL including anti-inflammatory agents, antimicrobials, calcium antagonists, vitamins, essential minerals, vasodilators, volume expanders, defibrinogenators, diuretics, hyperbaric oxygen, and bed rest. Currently, the regimen for SSNHL treatment consists of steroids (prednisone or methylprednisone, at an initial dose of $1 \mathrm{mg} / \mathrm{kg}$ of body weight per day for 5-14 days [Conlin and Parnes, 2007]). For SSNHL, 45-65\% of patients will regain their pre-loss hearing thresholds even without therapy, with average gains of $35 \mathrm{~dB}$. Spontaneous recovery without treatment can occur within 2 weeks $(30-$ $80 \%$ ), but the complete recovery occurs only in $35 \%$ of patients [Ryu et al., 2017].

The benefits of antioxidants are currently the focus of SSNHL as an adjuvant to the treatment. Recent reports suggested that free radicals, reactive oxygen species, and nitric oxide have toxic effects on the auditory system, particularly the outer hair cells. During normal mitochondrial respiration, reactive oxygen species (ROS) are produced, which can cause cell damage when generated in excess. During normal functioning they are converted to nonreactive molecules by endogenous antioxidants [Darrat et al., 2007]. However, disruption of this normally balanced system can result in overproduction of ROS, thus overwhelming the natural intrinsic defense and resulting in cell injury and death [Krämer et al., 2006] Administration of exogenous antioxidants may protect cells by scavenging the excess ROS, thereby pre- venting damage. Our study systematically reviewed and analyzed the effect of antioxidant vitamins (A, C, and E) impacting in the treatment outcomes for patients with SSNHL.

\section{Methods}

Data Sources

A thorough search of MEDLINE, EMBASE, PubMed, Web of Science and Cochrane Review was conducted, using the keywords "sudden hearing loss" or "SSNHL" or "vitamin" or "antioxidant" or "vitamin A" or "vitamin C" or "vitamin E" or "ascorbic acid," or "retinol." This systematic review included published studies from January 1, 1995, to September 25, 2017.

\section{Data Extraction}

A total of 446 potential manuscripts were identified using the keywords mentioned above. Only articles in English and French were included. Individual abstracts were screened to select the studies that followed the criteria for this review. Full texts of selected articles were then retrieved, rescreened for possible inclusion in the current review by two different observers independently.

\section{Data Presentation}

Randomized case-control studies were evaluated in order to investigate the effect of adding antioxidant vitamins to the traditional therapy of SSNHL. Controls received placebo treatments associated with conventional therapy (corticosteroid). The results of treatment of SSNHL are reported as: complete recovery, where hearing thresholds return back to their normal values before the onset of SSNHL; marked recovery, where more than $30 \mathrm{~dB}$ recovery in mean hearing level is reported; partial recovery, a recovery of $10-29 \mathrm{~dB}$ in mean hearing, and no response $(<10 \mathrm{~dB}$ in mean hearing level). Only patients showing complete recovery were included in the current review. Then, the effect of adjuvant antioxidant vitamin therapy was compared to placebo adjuvant therapy considering $100 \%$ recovery rates for both treatments.

\section{Data Synthesis}

The outcome was obtained by comparing the number of patients who had a complete recovery from SSNHL in both groups (with vs. without adjuvant therapy with antioxidant vitamins). The effect size was measured using the log relative risk because outcomes are reported in a dichotomous manner. Both random and fixed-effect models were used. Since the heterogeneity was very trivial $\left(\mathrm{I}^{2}=0.01 \%\right)$, using the fixed-effect model was acceptable; however, both model results did not contradict.

\section{Results}

Searching the databases screened the total of 446 studies. From these, 436 articles were excluded at abstract level because they were either animal studies, duplicates, or they tested other drugs or antioxidants (not vitamins) 
Fig. 1. Flow diagram of the search and study selection process.

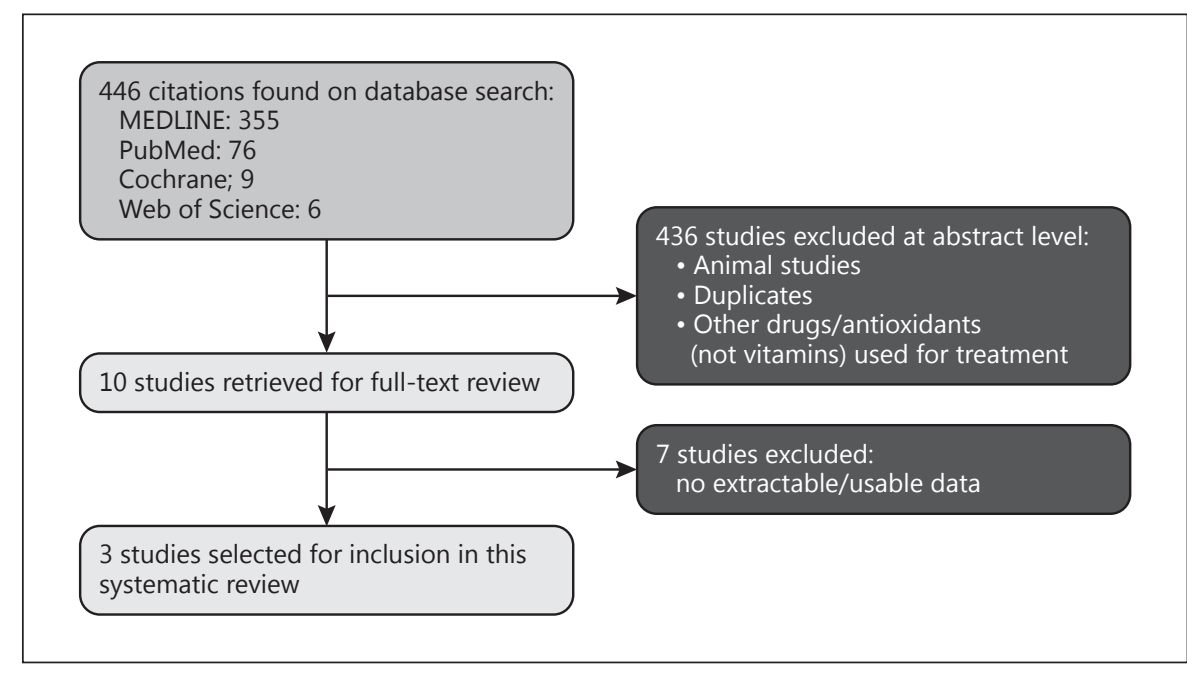

Table 1. Summary of results of all studies included in the systematic review $(n)$

\begin{tabular}{llllll}
\hline Study & $\begin{array}{l}\text { Vitamin } \\
\text { (improvement) }\end{array}$ & $\begin{array}{l}\text { Vitamin } \\
\text { (no improvement) }\end{array}$ & $\begin{array}{l}\text { Controls } \\
\text { (improvemnet) }\end{array}$ & $\begin{array}{l}\text { Controls } \\
\text { (no improvement) }\end{array}$ & $\begin{array}{l}\text { Vitamin } \\
\text { (total) }\end{array}$ \\
\hline Joachims et al. [2003], Israel, vitamin E & 13 & 20 & 11 & 22 & 33 \\
\hline Hatano et al. [2008], Japan, vitamins E, C & 18 & 31 & 4 & 34 & 49 \\
\hline $\begin{array}{l}\text { Kaya et al. [2015], Turkey, vitamins A, C, E, } \\
\text { selenium }\end{array}$ & 26 & 44 & 16 & 40 & 38 \\
\hline
\end{tabular}

(Fig. 1). Full texts of 10 publications were recovered, and then 6 of them were excluded because it was not possible to extract complete data (such as the number of patients who reached full recovery after administration of antioxidant vitamins). The remaining 3 studies were included for the systematic review. A summary of these 3 studies is presented in Table 1. For quality assessment, we used the Cochrane Collaboration tool for assessing risk of bias [Higgins et al., 2011]. The results are presented in Table 2.

The number of subjects with complete recovery in both vitamin versus placebo groups is shown in Table 1 .

It was difficult to pool the data from the 3 studies due to lack of consistency. While Joachims et al. [2003] investigated the effect of adding vitamin E, Hatano et al. [2008] looked at the effect of both vitamins E and C, and Kaya et al. [2015] also added vitamin A to vitamins E and C. All 3 studies found an improvement in the study group, which received the adjuvant vitamin therapy, compared to the control group, which received merely the standard corticosteroid therapy. However, this improvement was not significant in some studies. Details of each study result are discussed below.

Joachims et al. [2003] found that $39.39 \%$ of patients in the vitamin group (13 out of 33) experienced full recovery, compared to $33.33 \%$ of patients in the control group (11 out of 33). Joachims et al. set a success of treatment criterion, which is an improvement of $75 \%$ or more at the time of discharge (achieved by dividing hearing gain by the difference in hearing level between the affected and healthy ear). This criterion was achieved in $78.78 \%$ of patients in the vitamin group who experienced a success of treatment (26 out of 33), compared to $45.45 \%$ (15 out of 33) of patients in the control group. This difference was statistically significant. Joachims et al. [2003] discussed some factors that can affect the results of treatment. They reported that the severity of initial hearing loss can affect the recovery rate, which was also worse in patients who had vertigo and/or tinnitus at the time of the sudden loss of hearing as compared to those who did not experience those symptoms; however, the difference was not statistically significant. 
Table 2. Risk of bias assessment for all studies included in the systematic review

\begin{tabular}{|c|c|c|c|c|c|c|c|c|}
\hline Study, year & $\begin{array}{l}\text { Random } \\
\text { sequence } \\
\text { generation }\end{array}$ & $\begin{array}{l}\text { Allocation } \\
\text { sequence } \\
\text { concealment }\end{array}$ & $\begin{array}{l}\text { Blinding of the } \\
\text { participants }\end{array}$ & $\begin{array}{l}\text { Blinding of } \\
\text { the outcome } \\
\text { assessors }\end{array}$ & $\begin{array}{l}\text { Incomplete } \\
\text { outcome data } \\
\text { reporting }\end{array}$ & $\begin{array}{l}\text { Selective } \\
\text { reporting? }\end{array}$ & $\begin{array}{l}\text { Any other } \\
\text { potential } \\
\text { sources of } \\
\text { bias? }\end{array}$ & $\begin{array}{l}\text { Summary } \\
\text { assessment } \\
\text { of risk of } \\
\text { bias }\end{array}$ \\
\hline $\begin{array}{l}\text { Joachims } \\
\text { et al., } 2003\end{array}$ & $\begin{array}{l}\text { Low } \\
\text { Authors stated } \\
\text { that the study is } \\
\text { randomized }\end{array}$ & $\begin{array}{l}\text { Low } \\
\text { Authors stated } \\
\text { that the study is } \\
\text { double-blind }\end{array}$ & $\begin{array}{l}\text { Unclear } \\
\text { Measured, not } \\
\text { explained }\end{array}$ & $\begin{array}{l}\text { Unclear } \\
\text { Measured, not } \\
\text { explained }\end{array}$ & $\begin{array}{l}\text { High } \\
\text { Not all end points } \\
\text { were complete; } 8 \\
\text { patients in the } \\
\text { study group were } \\
\text { not reported in } \\
\text { the results section }\end{array}$ & $\begin{array}{l}\text { Low } \\
\text { None }\end{array}$ & $\begin{array}{l}\text { Low } \\
\text { None }\end{array}$ & Low \\
\hline $\begin{array}{l}\text { Hatano } \\
\text { et al., } 2008\end{array}$ & $\begin{array}{l}\text { Unclear } \\
\text { A retrospective } \\
\text { chart review - } \\
\text { no details } \\
\text { provided }\end{array}$ & $\begin{array}{l}\text { Unclear } \\
\text { A retrospective } \\
\text { chart review - } \\
\text { no details } \\
\text { provided }\end{array}$ & $\begin{array}{l}\text { Unclear } \\
\text { A retrospective } \\
\text { chart review - } \\
\text { no details } \\
\text { provided }\end{array}$ & $\begin{array}{l}\text { Unclear } \\
\text { A retrospective } \\
\text { chart review - } \\
\text { no details } \\
\text { provided }\end{array}$ & $\begin{array}{l}\text { n.a. (retrospective } \\
\text { study) }\end{array}$ & $\begin{array}{l}\text { Low } \\
\text { None }\end{array}$ & $\begin{array}{l}\text { Low } \\
\text { None }\end{array}$ & Unclear \\
\hline $\begin{array}{l}\text { Kaya et } \\
\text { al., } 2015\end{array}$ & $\begin{array}{l}\text { High } \\
\text { The authors } \\
\text { clearly stated } \\
\text { that the study } \\
\text { was not } \\
\text { randomized or } \\
\text { blinded }\end{array}$ & $\begin{array}{l}\text { High } \\
\text { The authors } \\
\text { clearly stated } \\
\text { that the study } \\
\text { was not } \\
\text { randomized or } \\
\text { blinded }\end{array}$ & $\begin{array}{l}\text { High } \\
\text { The authors } \\
\text { clearly stated } \\
\text { that the study } \\
\text { was not } \\
\text { randomized or } \\
\text { blinded }\end{array}$ & $\begin{array}{l}\text { High } \\
\text { The authors } \\
\text { clearly stated } \\
\text { that the study } \\
\text { was not } \\
\text { randomized or } \\
\text { blinded }\end{array}$ & $\begin{array}{l}\text { Low } \\
\text { Outcome data } \\
\text { were complete; no } \\
\text { exclusions/ } \\
\text { attritions were } \\
\text { reported }\end{array}$ & $\begin{array}{l}\text { Low } \\
\text { None }\end{array}$ & $\begin{array}{l}\text { Low } \\
\text { None }\end{array}$ & High \\
\hline
\end{tabular}

n.a., not applicable.

Hatano et al. [2008] reported a significant difference in final pure-tone average, hearing gain and recovery rate between the vitamins ( $\mathrm{C}$ and $\mathrm{E}$ ) group and the control group (Table 3). $36.7 \%$ of patients in the vitamin group (18 out of 49) experienced a complete recovery compared to $10.5 \%$ of the control group (4 out of 38 ). The vitamin group had a better final pure-tone average $(41.1 \mathrm{~dB}$ compared to $52.6 \mathrm{~dB}$ in the control group). The recovery rate was $63.3 \%$ in the vitamin group compared to $44.0 \%$ in the control group.

Finally, Kaya et al. [2015] found that the complete recovery rate was $37.1 \%$ ( 26 out of 70 ) in the vitamin (A, C, E) group compared to $28.5 \%$ (16 out of 56) in the control group. They reported that the mean final hearing level was $36.6 \pm 26.7 \mathrm{~dB}$ in the vitamin (A, C, E) group compared to $49.9 \pm 34.5 \mathrm{~dB}$ in the control group. The total recovery rate was also significantly better in the vitamin group (52.4 \pm $24.0 \%$ compared to $39.7 \pm 28.1 \%$ in the control group).

\section{Discussion}

The cause and appropriate treatment of SSNHL remain unclear. Over the last few years, many protocols have been suggested in the literature [Conlin and Parnes,
2007; Kaya et al., 2015]. This systematic review evaluated the effect of antioxidant vitamins (A, C, and E) impacting the treatment outcomes for patients with SSNHL.

Although the underlying mechanism of SSNHL remains unknown, ROS and reactive nitrogen species may contribute to the pathogenesis of SSNHL in the same way as in cases of ototoxicity, noise-induced hearing loss and presbyacusis. ROS generation starts with rapid uptake of oxygen, activation of NADPH oxidase, and the production of superoxide anion radical. In the ear, the cochlea, the organ of Corti which contains numerous hair cells, the vestibular organ, and neurons are the most susceptible structures to oxidative stress. Antioxidants are considered to be important radical scavengers to neutralize the oxidative stress by enhancing cellular defenses and then protect the cell membranes [Young and Woodside, 2001].

Animal models showed that antioxidants ameliorate idiopathic SSNHL. Despite the fact that only a few studies investigated the effect of antioxidants on SSNHL, most of them reported a significant improvement in the group of patients who receive antioxidants as an adjuvant treatment for SSNHL. The current analysis focused on vitamins ( $\mathrm{A}, \mathrm{C}$, and $\mathrm{E}$ ), because these are the major antioxidant vitamins. Each vitamin has a different mechanism of 
Table 3. Treatment regimens and audiometric results of all studies included in the systematic review

\begin{tabular}{|c|c|c|c|c|c|c|}
\hline Study, year & $\begin{array}{l}\text { Treatment protocol } \\
\text { (study group) }\end{array}$ & $\begin{array}{l}\text { Treatment protocol } \\
\text { (control group) }\end{array}$ & $\begin{array}{l}\text { Number } \\
\text { and age } \\
\text { (study } \\
\text { group) }\end{array}$ & $\begin{array}{l}\text { Number } \\
\text { and age } \\
\text { (control } \\
\text { group) }\end{array}$ & $\begin{array}{l}\text { Audiometric } \\
\text { results } \\
\text { (study group), } \\
n(\%)\end{array}$ & $\begin{array}{l}\text { Audiometric } \\
\text { results } \\
\text { (control group), } \\
n(\%)\end{array}$ \\
\hline $\begin{array}{l}\text { Joachims } \\
\text { et al., } 2003\end{array}$ & $\begin{array}{l}\text { In addition to the } \\
\text { control group } \\
\text { regimen, the study } \\
\text { group received oral } \\
\text { vitamin } E \text { (D- } \alpha \text { - } \\
\text { tocopherol acetate), } \\
400 \text { mg twice daily }\end{array}$ & $\begin{array}{l}\text { Bed rest, steroids } \\
\text { (prednisone at a dosage of } \\
1 \mathrm{mg} / \mathrm{kg} / \text { day), intravenous } \\
\text { magnesium sulfate } 4 \mathrm{~g} / \text { day, } \\
\text { and carbogen }\left(95 \% \mathrm{O}_{2}+\right. \\
\left.5 \% \mathrm{CO}_{2}\right) \text { by mask, } 30 \mathrm{~min} \\
4 \text { times a day }\end{array}$ & $\begin{array}{l}n=33 \\
\text { Age } \\
42.2 \pm 15.62 \\
\text { years }\end{array}$ & $\begin{array}{l}n=33 \\
\text { Age } \\
38 \pm 16.17 \\
\text { years }\end{array}$ & $\begin{array}{l}\text { Initial PTA } \\
67.6 \pm 19.8 \mathrm{~dB} \\
\text { Final PTA } \\
37.1 \pm 28.8 \mathrm{~dB} \\
\text { Complete recovery } \\
(39.39 \%) \\
\text { Good recovery }(39.39 \%) \\
\text { Moderate recovery } \\
(15.15 \%) \\
\text { None }(6.06 \%)\end{array}$ & $\begin{array}{l}\text { Initial PTA } \\
70.3 \pm 12.4 \mathrm{~dB} \\
\text { Final PTA } \\
47.6 \pm 25.2 \mathrm{~dB} \\
\text { Complete recovery } \\
(33.33 \%) \\
\text { Good recovery }(12.12 \%) \\
\text { Moderate recovery } \\
\text { (36.36\%) } \\
\text { None }(18.18 \%)\end{array}$ \\
\hline $\begin{array}{l}\text { Hatano } \\
\text { et al., } 2008\end{array}$ & $\begin{array}{l}\text { In addition to the } \\
\text { control group } \\
\text { regimen, oral } \\
\text { administration of } \\
\text { vitamin } \mathrm{E} \\
\text { (tocopherol } \\
\text { nicotinate, } 600 \mathrm{mg} / \\
\text { day) and vitamin C } \\
(1,200 \mathrm{mg} / \text { day) was } \\
\text { performed for at } \\
\text { least } 4 \text { weeks }\end{array}$ & $\begin{array}{l}\text { Prednisolone at an initial } \\
\text { dosage of } 1 \mathrm{mg} / \mathrm{kg} / \text { day } \\
\text { tapered over } 7 \text { days, ATP } \\
\text { and vitamin } B_{12} \text { were given } \\
\text { in both groups. Alprostadil, } \\
10 \text { mg lipo-PGE1 for } \\
7 \text { days, was administered in } \\
\text { cases with poor recovery } \\
\text { after steroid therapy }\end{array}$ & $\begin{array}{l}n=49 \\
\text { Age } \\
55.5 \pm 16.6 \\
\text { years }\end{array}$ & $\begin{array}{l}n=38 \\
\text { Age } \\
57.4 \pm 13.1 \\
\text { years }\end{array}$ & $\begin{array}{l}\text { Initial PTA } 70.1 \pm 18.4 \mathrm{~dB} \\
\text { Final PTA } \\
41.1 \pm 23.8 \mathrm{~dB} \\
\text { Complete recovery } \\
18(36.7 \%) \\
\text { Marked recovery } \\
6(12.2 \%) \\
\text { Slight recovery } \\
12(24.5 \%) \\
\text { No response } 13(26.5 \%)\end{array}$ & $\begin{array}{l}\text { Initial PTA } \\
71.2 \pm 24.0 \mathrm{~dB} \\
\text { Final PTA } \\
52.6 \pm 24.8 \mathrm{~dB} \\
\text { Complete recovery } \\
4(10.5 \%) \\
\text { Marked recovery } \\
7(18.4 \%) \\
\text { Slight recovery } \\
13(34.2 \%) \\
\text { No response } \\
14(36.8 \%)\end{array}$ \\
\hline $\begin{array}{l}\text { Kaya } \\
\text { et al., } 2015\end{array}$ & $\begin{array}{l}\text { Same as control } \\
\text { group plus: } \\
\text { vitamin A (natural } \\
\beta \text {-carotene, } 26,000 \\
\text { IU) } \\
\text { vitamin C (ascorbic } \\
\text { acid, } 200 \mathrm{mg} \text { ) } \\
\text { vitamin } \mathrm{E}(\mathrm{D}-\alpha \text { - } \\
\text { tocopherol, } 200 \mathrm{IU}) \\
\text { selenium }(50 \mu \mathrm{g}) \\
\text { twice daily for } \\
30 \text { days + control } \\
\text { group idiopathic } \\
\text { SSNHL treatment } \\
\text { regimen }\end{array}$ & $\begin{array}{l}\text { Methylprednisolone } \\
\text { at an initial dose of } \\
1 \mathrm{mg} / \mathrm{kg} \text { body weight per } \\
\text { day, tapered over } 14 \text { days } \\
\text { Rheomacrodex } \\
\text { ([10 } \mathrm{g} \text { of dextran and } \\
0.9 \mathrm{~g} \text { of } \mathrm{NaCl}] / 100 \mathrm{~mL}) \\
500 \mathrm{~mL} \text { daily for } 5 \text { days } \\
\mathrm{Vastarel}^{\circledR} 20 \text {-mg tablet } \\
(20 \mathrm{mg} \text { of trimetazidine } \\
\text { dihydrochloride) } 3 \text { times } \\
\text { daily for } 30 \text { days } \\
\text { Ten } 60 \text {-min HBO sessions } \\
(2.5 \text { absolute atmospheres } \\
\left.\text { of } 100 \% \mathrm{O}_{2}\right) \text {, once daily, } \\
\text { starting on the day of } \\
\text { hospitalization }\end{array}$ & $\begin{array}{l}n=56 \\
\text { Age } \\
42.4 \pm 14.1 \\
\text { years }\end{array}$ & $\begin{array}{l}n=70 \\
\text { Age } \\
42.8 \pm 14.9 \\
\text { years }\end{array}$ & $\begin{array}{l}\text { Initial PTA } \\
72.9 \pm 24.8 \mathrm{~dB} \mathrm{HL} \\
\text { Final PTA } 36.6 \pm 26.7 \mathrm{~dB} \mathrm{HL} \\
\text { Complete recovery } \\
26(37.1 \%) \\
\text { Marked recovery } \\
26(37.1 \%) \\
\text { Slight recovery } \\
8(11.4 \%) \\
\text { No response } \\
10(14.2 \%)\end{array}$ & $\begin{array}{l}\text { Initial PTA } \\
77 \pm 24.5 \mathrm{~dB} H \mathrm{HL} \\
\text { Final PTA } 49.9 \pm 34.5 \mathrm{~dB} \\
\text { HL } \\
\text { Complete recovery } \\
16(28.5 \%) \\
\text { Marked recovery } \\
11(19.6 \%) \\
\text { Slight recovery } \\
13(23.2 \%) \\
\text { No response } \\
16(28.5 \%)\end{array}$ \\
\hline
\end{tabular}

IU, international unit; PTA, pure-tone average; dB HL, decibel hearing level; PGE1, prostaglandin E1; ATP, adenosine triphosphate disodium; HBO, hyperbaric oxygen.

action, e.g. vitamin A can reduce the concentration of singlet oxygen and repair damaged hair cells, vitamin E can reduce peroxyl radicals in the cell membrane, and vitamin $\mathrm{C}$ can detoxify free radicals in the aqueous phase. Hence, those vitamins can significantly improve the outcome of the management of SSNHL [Hatano et al., 2008; Kaya et al., 2015].

The 3 studies retrieved for review found higher complete recovery rates in the vitamin group compared to the placebo group; the fact that heterogeneity among studies is negligible $(0.01 \%)$ strengthens the results, and the significance of the current review pointed to a homogeneous population, with minimal variability among them. However, and due to the different vitamin combinations used, it was not possible to pool the results in a meta-analysis study.

Although the vitamin group showed better results in the recovery progress, only the complete recovery patients were of interest to discuss to have a more robust conclusion. 
There are a few postulated pathophysiologies for SSNHL: (1) labyrinthine viral infection - there is a moderate prevalence of recent viral-type illness in SSNHL patients; about $17-33 \%$ of SSNHL patients recall a recent viral illness; however, $25 \%$ of patients without hearing loss visiting an otolaryngology clinic had experienced a virallike illness within a month [Okamoto et al., 1994]; (2) labyrinthine vascular compromise - the cochlea is an end organ with no collateral vasculature; thrombosis, embolus, vasospasm, or any pathology that results in reduced blood flow to the cochlea is a possible etiology for idiopathic SSNHL [Rudack et al., 2006]; (3) intracochlear membrane ruptures - rupture of either the membranes that separate the inner ear from the middle ear, or the delicate membranes within the cochlea that separate the perilymphatic and endolymphatic spaces could result in SSNHL, by creating a state of relative endolymphatic hydrops or altering the endocochlear potential, respectively [Chung et al., 2014; Goodhill et al., 1973; Simmons, 1968]; (4) immunemediated inner ear disease - the occurrence of SSNHL in autoimmune diseases, such as Cogan syndrome and systemic lupus erythematosus, is well documented, and (5) iron deficiency anemia [Chung et al., 2014]. Iron, in addition to zinc and copper, is essential to break down the free radicals for the enzymatic antioxidants.

It is possible that any pathological condition resulting from one or more of these postulated mechanisms can result in idiopathic SSNHL, because no one mechanism could individually explain all cases of idiopathic SSNHL.

Since vascular compromise of the cochlea is one of the postulated mechanisms for SSNHL, the protective role of antioxidant vitamins in treating SSNHL can be understood. Maintaining a good balance between oxidative byproducts, such as free radicals, and protective substances, such as antioxidants, is important to prevent ischemia and reperfusion injury [Hatano et al., 2008].

The current study has some limitations. There is a lack of available data about which antioxidant vitamin is more effective, what is the therapeutic dosage and for what duration. In addition, some studies investigated the effect of multiple vitamins, and some looked at 1 vitamin. This would make the conclusion of the current study less accurate, since not enough studies were performed on each vitamin separately, and they did not compare the results with various vitamin combinations. It should be mentioned too that 1 study [Kaya et al., 2015] was not randomized or blinded, and hence it had a high risk of bias.

In sum, more studies are required in order to find out which specific vitamin or which combination of vitamins can yield the best outcome.

\section{Conclusion}

Our systematic review investigated the effect of adding antioxidant vitamins such as vitamin A (retinol), vitamin $\mathrm{C}$ (ascorbic acid), and vitamin E (either used individually or in combination) as adjuvant therapy to the current standard treatment (corticosteroids) for SSNHL. Based on the reviewed data, we cannot recommend to add antioxidant vitamins to corticosteroids. The percentage of patients with complete recovery was highest in individuals who used vitamins associated with the conventional treatment. However, the evidence so far is inconclusive with regard to which vitamin or vitamin combination(s) is more effective, and in what dosage. Further studies are required to test the effect of each vitamin individually, as well as giving different combinations of these vitamins in order to find the most effective vitamin and/or combination of vitamins to be routinely administered as an adjuvant therapy alongside with corticosteroids for the treatment of SSNHL.

\section{Acknowledgments}

The authors would like to thank the McGill Medical librarians for their valuable assistance in building the search strategy and retrieving the articles from the various databases. Funding was granted by the Canada Graduate Scholarship Master's (CGS-M) Award - Canadian Institutes of Health Research (CIHR).

\section{Disclosure Statement}

The authors declare that there is no conflict of interest regarding the publication of this paper.

References

Alexander TH, Harris JP: Incidence of sudden sensorineural hearing loss. Otol Neurotol 2013;34:1586-1589.

Chung S-D, Chen P-Y, Lin H-C, Hung S-H: Sudden sensorineural hearing loss associated with iron-deficiency anemia: a populationbased study. JAMA Otolaryngol Head Neck Surg 2014;140:417-422.

Conlin AE, Parnes LS: Treatment of sudden sensorineural hearing loss. I. A systematic review. Arch Otolaryngol Head Neck Surg 2007;133:573-581.

Darrat I, Ahmad N, Seidman K, Seidman MD: Auditory research involving antioxidants. Curr Opin Otolaryngol Head Neck Surg 2007; 15:358-363. 
Goodhill V, Harris I, Brockman SJ, Hantz O: Sudden deafness and labyrinthine window ruptures: audio-vestibular observations. Ann Otol Rhinol Laryngol 1973;82:2-12.

Hatano M, Uramoto N, Okabe Y, Furukawa M, Ito $\mathrm{M}$ : Vitamin $\mathrm{E}$ and vitamin $\mathrm{C}$ in the treatment of idiopathic sudden sensorineural hearing loss. Acta Otolaryngol 2008;128:116121.

Higgins JPT, Altman DG, Gotzsche PC, et al: The Cochrane Collaboration's tool for assessing risk of bias in randomised trials. BMJ 2011; 343:d5928.

Joachims HZ, Segal J, Golz A, Netzer A, Goldenberg D: Antioxidants in treatment of idiopathic sudden hearing loss. Otol Neurotol 2003; $24: 572-575$.
Kaya H, Koç AK, Sayın İ, et al: Vitamins A, C, and $\mathrm{E}$ and selenium in the treatment of idiopathic sudden sensorineural hearing loss. Eur Arch Otorhinolaryngol 2015;272:1119-1125.

Krämer OH, Baus D, Knauer SK, et al: Acetylation of Stat 1 modulates NF-kappaB activity. Genes Dev 2006;20:473-485.

Lanvers-Kaminsky C, Zehnhoff-Dinnesen A, Parfitt R, Ciarimboli G: Drug-induced ototoxicity: mechanisms, pharmacogenetics, and protective strategies. Clin Pharmacol Ther 2017;101:491-500.

Okamoto M, Shitara T, Nakayama M, et al: Sudden deafness accompanied by asymptomatic mumps. Acta Otolaryngol Suppl 1994;514: $45-48$.
Rudack C, Langer C, Stoll W, Rust S, Walter M: Vascular risk factors in sudden hearing loss. Thromb Haemost 2006;95:454-461.

Ryu IY, Park SH, Park EB, Kim HJ, Kim SH, Yeo SG: Factors prognostic of season-associated sudden sensorineural hearing loss: a retrospective observational study. J Audiol Otol 2017;21:44-48.

Simmons FB: Theory of membrane breaks in sudden hearing loss. Arch Otolaryngol 1968;88: 41-48.

WHO: Deafness and hearing loss. http://www. who.int/mediacentre/factsheets/fs300/en/ (accessed March 27, 2017).

Young IS, Woodside JV: Antioxidants in health and disease. J Clin Pathol 2001;54:176-186. 